\title{
Belgeo
}

Revue belge de géographie

4 | 2004

Maritime and port economic geography

\section{The cruise shipping industry in the corporate mergers and overpanamax eras. A comparison with the container shipping industry}

Le secteur des croisières à l'heure des fusions armatoriales et des unités overpanamax. Une comparaison avec le secteur des conteneurs

\section{Jacques Charlier}

\section{OpenEdition}

\section{Journals}

Electronic version

URL: http://journals.openedition.org/belgeo/13517

DOI: 10.4000/belgeo.13517

ISSN: 2294-9135

Publisher:

National Committee of Geography of Belgium, Société Royale Belge de Géographie

Printed version

Date of publication: 31 December 2004

Number of pages: $433-460$

ISSN: 1377-2368

Electronic reference

Jacques Charlier, "The cruise shipping industry in the corporate mergers and overpanamax eras. A comparison with the container shipping industry », Belgeo [Online], 4 | 2004, Online since 15

September 2013, connection on 01 May 2019. URL : http://journals.openedition.org/belgeo/13517 ; DOl : 10.4000/belgeo.13517

This text was automatically generated on 1 May 2019.

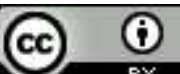

Belgeo est mis à disposition selon les termes de la licence Creative Commons Attribution 4.0 International. 


\title{
The cruise shipping industry in the corporate mergers and overpanamax eras. A comparison with the container shipping industry
}

\author{
Le secteur des croisières à l'heure des fusions armatoriales et des unités \\ overpanamax. Une comparaison avec le secteur des conteneurs
}

Jacques Charlier

1 Cruise shipping is one of the hottest segments of the shipping industry (Peisley, 1997 and 2004; Wild \& Dearing, 1999 and 2004a) and is characterized by a series of similarities with the recent evolution of the container shipping industry. The geographical dimension of its globalization has already been explored in two edited books (Casteljon \& Charlier, 2000; Dowling, 2004), as well as in a few papers, including a previous series from this author (Arnold \& Charlier, 1999; Charlier, 1996 and 2000a; Charlier \& Arnold, 1997), as well as in a recent book chapter (Hall, 2004), but little has been written about the corporate and technical dimensions of this process. This paper aims at filling partly the gap by establishing a qualitative comparison between the container and cruise shipping industries, by focussing here upon two unexplored dimensions, namely on the one hand the ownership structure and the concentration process it has experienced, and on the other hand the increasing size of the vessels and the rise of overpanamax-sized ships. Many authors refer to postpanamax ships, but this is not a question of evolution in time, actually; as this is a matter of size, we feel that overpanamax is a more appropriate term, and this will be used systematically hereafter. Panamax-sized ships are able to transit the Panama Canal, whose locks accept vessels with a beam up to $32.3 \mathrm{~m}$, and overpanamax ships are therefore too wide to enter into the Panama locks, whereas infrapanamax vessels fit more or less easily into the locks. However, this is also a question of length, as Panama's locks only allow the transit of cruise ships up to $294.5 \mathrm{~m}$ long (and slightly less for containerships). 
2 As the container industry is much more well-known than cruise shipping, these two industries will not be dealt with here on equal foot, and more space will be devoted to the second than to the first. Therefore, only second-hand statistical material will be used when referring to containers in the first section, whereas all the figures quoted at the third section for the cruise industry are original and are the product of a specific statistical research for this paper. As far as the geographical background is concerned, in itself the topic of another paper, container shipping is, for many years, a global industry (Slack, 1998 and 1999), whereas cruise shipping is still in a process of spatial expansion. Most of its offer is currently in North American or European waters, but there is a big medium- and long term potential for the Asia-Pacific region. By contrast, as for container shipping, cruising in the waters of the developing world (especially intertropical Africa) will remain marginal in the foreseeable future.

\section{Container shipping in the overpanamax and corporate mergers eras}

According to the 2003 issue of Containerisation International's Yearbook, the leading source for the container industry, the world fully cellular fleet (a cellular ship is a container ship with cell guides in its holds) amounted to 2,981 ships as at 01-11-2002 (Table 1). For the first time in maritime history, its overall carrying capacity reached 6 million TEUs, or Twenty Equivalent Units (Table 2). These are standard containers with a length of 20 feet, and a 40 feet container accounts thus for two TEUs. The capacity of container ships is always shown in TEUs, whereas they usually carry a combination of 20 and 40 feet boxes (there is a trend towards longer containers of 45 or 48 feet, but the TEU is nowadays a well-established measurement unit).

Table 1. Structure of the world container fleet as at 01-11-2002 by number of ocean-going ships.

\begin{tabular}{|c|c|c|c|c|c|c|}
\hline & \multicolumn{3}{|c|}{ Ships in service } & \multicolumn{3}{|c|}{ Ships on order } \\
\hline & $\begin{array}{l}\text { Fuly } \\
\text { cellular }\end{array}$ & $\begin{array}{c}\text { Other } \\
\left.\text { types( }{ }^{*}\right)\end{array}$ & $\begin{array}{l}\text { Grand } \\
\text { total }\end{array}$ & $\begin{array}{l}\text { Fully } \\
\text { cellular }\end{array}$ & $\begin{array}{c}\text { Other } \\
\text { types (0) }\end{array}$ & $\begin{array}{c}\text { Grand } \\
\text { total }\end{array}$ \\
\hline$<3,000$ TEUS & 2,309 & 4,263 & 6,472 & 162 & 62 & 224 \\
\hline$<1,000$ TEUs & 963 & 3.886 & 4.849 & 47 & 27 & 74 \\
\hline $1,000-1,999$ & 889 & 377 & 1,266 & 47 & 25 & 72 \\
\hline $2,000-2,999$ & 457 & 30 & 487 & 68 & 10 & 78 \\
\hline$>3,000$ TEUS & 672 & - & 672 & 149 & - & 149 \\
\hline $3,000-3,999$ & 270 & - & 270 & 19 & - & 19 \\
\hline $4,000-4,999$ & 193 & - & 193 & 61 & - & 61 \\
\hline$\geq 5,000$ TEUS & 209 & - & 209 & 69 & - & 69 \\
\hline Overall & 2,981 & 4,263 & 7,274 & 311 & 62 & 373 \\
\hline
\end{tabular}

${ }^{\star}$ ) Includes conbulkers, conros, roros, semi-containerships, multipurpose vessels and container/ barge carriers

COMPUTED FROM CONTAINERISATION INTERNATIONAL'S YEARBOOK 2003 
Table 2. Structure of the world container fleet as at 01-11-2002 by number of slots ('000 TEUs).

\begin{tabular}{|c|c|c|c|c|c|c|}
\hline & \multicolumn{3}{|c|}{ Ships in service } & \multicolumn{3}{|c|}{ Ships on order } \\
\hline & $\begin{array}{l}\text { Fully } \\
\text { collular }\end{array}$ & $\begin{array}{l}\text { Other } \\
\text { types(") }\end{array}$ & $\begin{array}{c}\text { Grand } \\
\text { total }\end{array}$ & $\begin{array}{l}\text { Fully } \\
\text { cellular }\end{array}$ & $\begin{array}{l}\text { Other } \\
\text { bypes (*) }\end{array}$ & $\begin{array}{l}\text { Grand } \\
\text { total }\end{array}$ \\
\hline$<3,000$ TEUs & 2,997 & 1,750 & 4,747 & 277 & 85 & 362 \\
\hline$<1,000$ TEUS & 516 & 1,176 & 1.682 & 37 & 20 & 57 \\
\hline $1,000-1,999$ & 1,251 & 505 & 1,756 & 69 & 44 & 113 \\
\hline $2,000-2,999$ & 1,130 & 69 & 1,199 & 171 & 21 & 192 \\
\hline$>3,000$ TEUS & 3,004 & - & 3,004 & 761 & - & 761 \\
\hline $3,000-3,999$ & 927 & - & 927 & 62 & - & 62 \\
\hline $4,000-4,999$ & 846 & - & 846 & 268 & - & 268 \\
\hline$\geq 5,000 \mathrm{TEUs}$ & 1.231 & - & 1,231 & 431 & - & 431 \\
\hline Overall & 6,001 & 1,750 & 7,751 & 1,038 & 85 & 1,123 \\
\hline
\end{tabular}

$\left.{ }^{\star}\right)$ Includes conbulkers, conros, roros, semi-containerships, multipurpose vessels and container/ barge carriers

COMPUTED FROM CONTAINERISATION INTERNATIONAL'S YEARBOOK 2003

5 Taking into consideration other types of vessels also able to take containers aboard, such as conbulkers, conros, roros, semi-containerships, multipurpose vessels and container/ barge carriers, the world container fleet amounted then to 7,274 ocean-going ships, with a total theoretical carrying capacity of nearly 7.3 million TEUs (however, this is less in the real shipping world, as the additional 4,263 non cellular vessels do not carry only containers). Even if more recent data are currently available, we will refer hereafter to capacity figures registered at the end of 2002 in order to compare the state of the container industry with that of the cruise industry in early 2003 when the latter faced a major change in its corporate structure. Even if the situation has changed somewhat since that time, this was the most appropriate time for such a comparison as far as the concentration degree of both industries is concerned. Therefore, many of the vessels shown in our tables as on order have been delivered in the meantime, and other new orders have been placed in 2003 and 2004 for container ships as for cruise ships.

6 As seen before for the tanker and dry bulk industries (Hilling \& Browne, 1998), container shipping lines have developed their fleets by ordering bigger vessels in order to meet an ever increasing demand, in a typical search for economies of scale (Lim, 1998; Cullinane \& Khanna, 2000; Cariou, 2000; Wild \& Dearing, 2004b). However, they faced more constraints, because of the need to serve a much higher number of ports (Marcadon, 2004), many of them with draft restrictions. Another reason was the willingness of many container lines to stay, when ordering panamax-sized ships, within the limits of the dimensions of the locks of the Panama Canal in order to be able to deploy their vessels as flexibly as possible. Nevertheless, after a first order of five overpanamax-sized vessels for the transpacific trade in 1988, some container lines started ordering overpanamax-sized ships in the early nineties, and the overpanamax fleet amounted to 247 units by the end of 2002, with at that time another 56 mega ships on order for delivery in 2003 or later (Figure 1). 
Figure 1. The rise of the overpanamax-sized container fleet (number of ships).

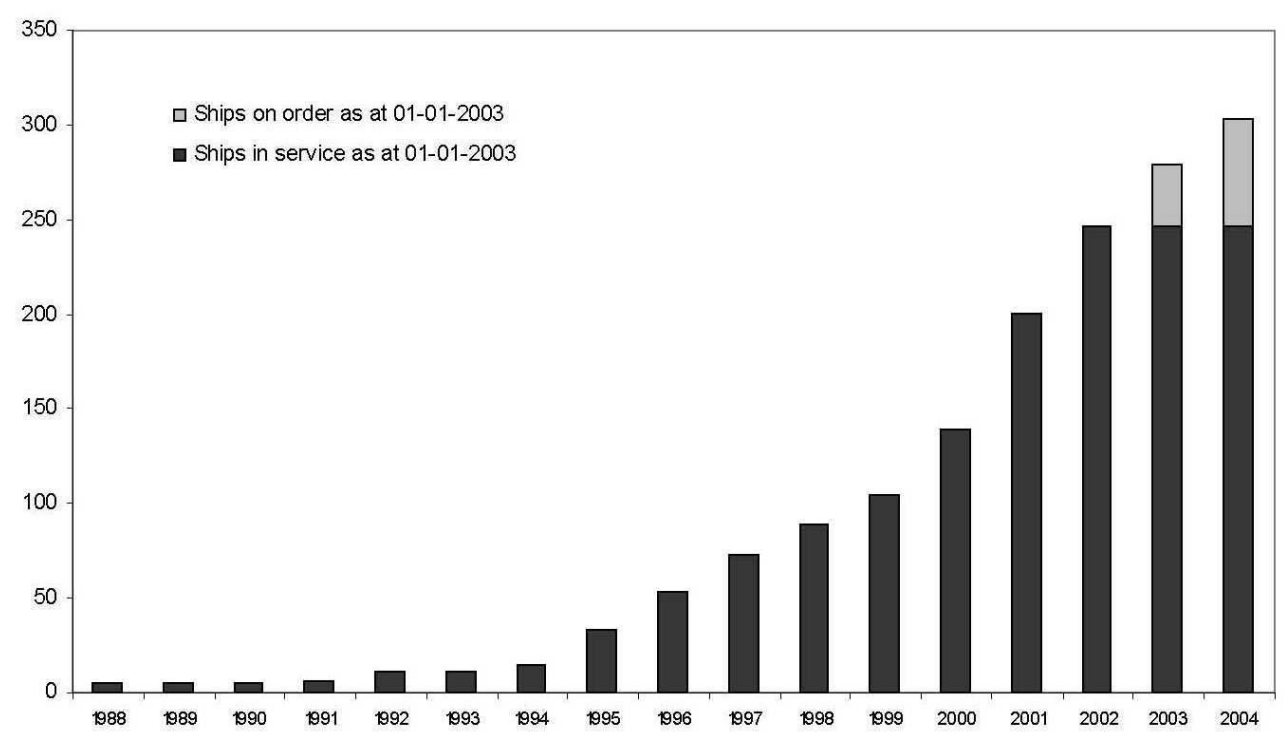

7 As can be seen at Tables 1 and 2, the carrying capacity is a major structural factor in the container carrying fleet. All non cellular vessels in service or on order carried less than 3,000 TEUs. The 672 fully cellular ships carrying more than 3,000 TEUs in service had a capacity of 3 million TEUs, that is 50 per cent of the whole of the cellular fleet and nearly 40 per cent of the whole container fleet; and capacity wise, the 149 fully cellular containerships of more than 3,000 TEUs on order accounted for the bulk of the container fleet on order. Within the very large ships category, the 209 Very Large Container Ships (VLCS) of more than 5,000 TEUs in service accounted, with 1.2 million TEUs, for 20 per cent of the fully cellular fleet, whereas the 69 such vessels on order represented more than 40 per cent of the fleet on order. All of these, as well as some of those carrying between 4,000 and 5,000 TEUs, are overpanamax-sized, and the overpanamax vessels accounted for about 1,442,000 TEUs for the fleet in service (that is 24 per cent of the carrying capacity of the cellular fleet and, overall, 19 per cent of the container fleet), and for about 498,000 TEUs for the fleet on order (that is 48 and 44.5 per cent, respectively). As can be seen, the world container fleet in general and the cellular fleet in particular are experiencing a never ending race towards bigger vessels, the largest of which on order have now reached the psychological mark of 10,000 TEUs in 2004.

8 As an original side note, one should point that this recent evolution has already had and will have quite dramatic consequences upon the world quayside container crane fleet, where the share of overpanamax-sized cranes is much higher, actually, than the share of overpanamax ships in the world container ocean-going fleet. This is because port authorities were not only obliged to follow the trend towards wider vessels, but to anticipate it, in order to retain existing customers and to try to attract new ones. The very same will happen in due time for cruise ports, for which the share of those able to handle overpanamax cruise ships will be much higher in the port universe than the actual share of these vessels in the world cruise fleet.

According again to Containerisation International, 3,109 container cranes were in service by the end of the year 2002 (including 105 barge handling cranes, actually), and 1,285 of these were overpanamax-sized, that is more than 40 per cent of them (Table 3). They 
were either built before 1998 (667) or after (618), but most of those recently built had a very large outreach, between 50.0 and $56.0 \mathrm{~m}$ (262) or higher (194) ; moreover, most of those on order ( 77 out of an overpanamax-sized subtotal of 131 and out of a grand total of 153) were of the largest variety. This shows that the container shipping industry has not only entered into the VLCS era but also into the VLCG era (standing for Very Large Container Gantries). And as for tankers and bulkers, the days of the ultra ships (ULCS, for Ultra Large Container Ships) and Ultra Large Container Gantries (ULCG) are on the horizon, with however a more limiting technical factor for the cranes. And in the same way as first generation cellular containerships are being phased out and scrapped, already 162 container gantries out of the 3,271 built prior to 2003 have been scrapped, virtually all of them panamax-sized; within these, nearly all were featuring a small outreach (less than $38.0 \mathrm{~m})$.

Table 3. Technical structure of the world quayside gantry crane fleet as at 01-11-2002.

\begin{tabular}{lrrrrr}
\hline & $\begin{array}{r}\text { Pre- } \\
1998\end{array}$ & $\begin{array}{c}1998- \\
2002\end{array}$ & $\begin{array}{c}\text { Current } \\
\text { total }\end{array}$ & $\begin{array}{c}\text { On } \\
\text { order }\end{array}$ & $\begin{array}{c}\text { Already } \\
\text { scrapped }\end{array}$ \\
\hline $\begin{array}{l}\text { Panamax-sized } \\
<38.0 \text { m outreach }\end{array}$ & 1,584 & 240 & 1,824 & 22 & $(159)$ \\
$38.0-43.9 \mathrm{~m}$ & 1,069 & 142 & 1,211 & 10 & $(151)$ \\
& 515 & 98 & 613 & 12 & $(8)$ \\
Overpanamax-sized & & & & & \\
$44.0-49.9 \mathrm{~m}$ & 667 & 618 & 1,285 & 131 & $(3)$ \\
$50.0-55.9 \mathrm{~m}$ & 566 & 170 & 733 & 25 & $(3)$ \\
$>56.0$ m outreach & 93 & 262 & 355 & 29 & $(-)$ \\
& 8 & 186 & 194 & 77 & $(-)$ \\
\hline Overall & 2,251 & 858 & 3,109 & 153 & $(162)$ \\
\hline
\end{tabular}

Includes 105 barge handling cranes, all of the smaller size.

Source: Containerisation International's Yearbook 2003

Another major specific feature of the container shipping industry is that, unlike the tanker and dry bulk industries, it has been characterized by a steady concentration process as far as capitalistic ownership of the container lines is concerned. This is besides ad hoc technical and sometimes commercial alliances whose configuration has been always evolving. Nowadays, most are technical vessels sharing agreements, known as VSAs, instead of more integrated consortia (Slack, Comtois \& McCalla, 2001). As Table 4 shows, the twenty largest players operated between themselves by the end of 2002 some 1,927 container carrying ships (most of them cellular) with an overall TEU capacity of nearly 4.8 million TEUs, that is 61.5 per cent of the world container fleet at that time (and a much higher proportion of the purely cellular fleet). And for the ten largest players, the figures were, respectively, 1,357 vessels, 3.4 million TEUs and 43.5 per cent, with 312 ships, 775,000 TEUs and around 10 per cent for the world largest operator, namely the AP Moller Group. The latter includes Maersk Sealand (itself resulting from a merger between the first and third container lines of the time, namely Maersk and Sealand), and Safmarine (incorporating itself the former liner shipping division of the Belgian CMB group). This group was weighting slightly less than the combined fleets of two of the current second, third and four largest operators, namely MSC, P\&O Nedlloyd and the Evergreen group (183, 160 and 143 vessels respectively, for about 400,000 TEUs each). 
Table 4. The fleet of the twenty largest container operators as at 01-11-2002.

\begin{tabular}{|c|c|c|c|c|}
\hline & \multicolumn{2}{|c|}{ Ships in service } & \multicolumn{2}{|c|}{ Ships on order } \\
\hline & Ships & $\begin{array}{l}\text { TEUs } \\
\left(000^{\prime}\right)\end{array}$ & Ships & $\begin{array}{l}\text { TEUs } \\
\left(000^{\prime}\right)\end{array}$ \\
\hline $\begin{array}{l}\text { AP Moller Group (1) } \\
\text { MSC } \\
\text { PSO Nedlloyd Group } \\
\text { Evergreen Group (2) } \\
\text { Hanjin / Senator } \\
\text { Cosco } \\
\text { APL (part of NOL) } \\
\text { CMA CGM } \\
\text { MOL Lines } \\
\text { CP Ships (3) } \\
\text { NYK } \\
\text { K Line } \\
\text { Zm } \\
\text { OOCL } \\
\text { CSCL } \\
\text { Hapag-Lloyd } \\
\text { Hyundai } \\
\text { Yang Ming } \\
\text { PIL Group } \\
\text { CSAV Group }\end{array}$ & $\begin{array}{r}312 \\
183 \\
160 \\
143 \\
81 \\
140 \\
71 \\
107 \\
68 \\
92 \\
73 \\
56 \\
71 \\
50 \\
88 \\
38 \\
32 \\
40 \\
83 \\
39\end{array}$ & $\begin{array}{r}774 \\
414 \\
407 \\
398 \\
304 \\
256 \\
229 \\
225 \\
189 \\
188 \\
178 \\
168 \\
165 \\
157 \\
148 \\
136 \\
123 \\
120 \\
98 \\
91\end{array}$ & $\begin{array}{r}22 \\
17 \\
14 \\
3 \\
5 \\
-1 \\
4 \\
14 \\
8 \\
14 \\
9 \\
2 \\
6 \\
11 \\
17 \\
6 \\
2 \\
7 \\
4 \\
3\end{array}$ & $\begin{array}{r}99 \\
93 \\
38 \\
10 \\
28 \\
19 \\
19 \\
62 \\
36 \\
54 \\
56 \\
7 \\
30 \\
61 \\
90 \\
42 \\
10 \\
27 \\
9 \\
9\end{array}$ \\
\hline
\end{tabular}

\section{INCLUDES MAERSK SEALAND, SAFMARINE, PORTLINK AND TORM LINE}

(2) INCORPORATES UNIGLORY AND INCLUDES LLOYD TRIESTINO

(3) INCLUDES CANMAR, CAST, LYKES, CONTSHIP, TMM, ITALIA AND ANZDL

SOURCE: CONTAINERISATION INTERNATIONAL'S YEARBOOK 2003

11 However, these are global figures, and the concentration between a few major players is often higher on some major trades and within these on specific routes. There is no room here to trace the history of the mergers and acquisitions characterizing the container industry, and suffice is to remind that, among the ten largest operators, Maersk Sealand is the product of a merger, as well as P\&O Nedlloyd, Hanjin/Senator, APL (integrating NOL's container division) or CMA CGM. Moreover, the Evergreen group has absorbed its former subsidiary Uniglory and incorporates Lloyd Triestino, whereas the fleets of Canmar, Cast, Lykes, TMM, Italia and ANZDL are combined into CP Ships (Alix, slack \& Comtois, 1999). This was leaving only MSC, Cosco and MOL as the only independent operators in the top ten of the time whose growth has been wholly or mainly organic. Since the end of 2002, the ranking of the main lines has changed somewhat but the concentration degree of the container shipping industry has not been modified significantly, as no major merger or acquisition has taken place.

For an outsider, container shipping may look like a quite concentrated industry, but the concentration process is more advanced, actually, in a much younger and smaller industry like cruise shipping. Container shipping is still a segment of the shipping industry characterized by a relatively high number of players, even if it is obviously experiencing a concentration phase under the pressure of globalisation and of the need to provide therefore global shipping networks (Frémont \& Stoppé, 2004). There is probably room for more mergers or acquisitions in this segment of the shipping industry, perhaps not in the top four or five because of the antitrust rules in the United States and in Europe, but below in the ranking. And there is also no doubt that, like for container ports, the Chinese lines will rise significantly by organic growth or externally (at the end of 
2002, Cosco and CSCL ranked, respectively, as the 6th and 15th container lines, and their more recent growth has been quite dramatic, especially CSCL's).

\section{Two industries facing a dramatic expansion of demand}

The major container lines entered into the organic growth and/or consolidation race, as well as into the overpanamax era for a quite simple reason, namely the dramatic growth of world trade in general and of seaborne container traffic in particular in the last two decades. The latter is well documented qualitatively, but it is more difficult to quantify precisely, as past figures are quite different from one source to another. A rather simple, yet robust, proxy of the rhythm of growth of the container industry is offered by the cumulative TEU traffic of the 50 largest container ports in the world, as computed from past and current issues of Containerisation International's Yearbook. They show that these leading fifty ports (the list of which has been changing over time, with always more Asian ports entering into the top 50) grew from 14.9 million TEUs in 1974 to 35.9 million TEUs in 1984, 90.2 million TEUs in 1994 and 207.2 million TEUs in 2003. The growth rates were most impressive: +140 per cent between 1974 and 1984, +151.5 per cent between 1984 and 1994, and +129.5 per cent between 1994 and 2003, a sustained growth especially fuelled in the last decade by the dramatic rise of continental China.

For the cruise industry, the statistical picture is also not easy to draw, because comprehensive figures are not available, strangely enough. The only reliable source about the evolution of the main geographic segment of the demand is the New York-base Cruise Lines International Association (CLIA), but this covers only the US-based lines or the foreign lines operating on the North American market. Their 25 member lines and the competitors included in their figures carried about 8.60 million passengers in 2002 (CLIA, 2004). However, the world grand total is far higher, as a series of lines are excluded from CLIA's figures because they are offering cruises only to non American passengers, especially Europeans and Asians. The British Maritime Evaluation Group (MEG) has suggested that, actually, the world total was as high as 12.20 million passengers in 2002 (Ward, 2004), but no similar estimates are available for the previous years, unfortunately.

The dynamics of the market can therefore only be appreciated, yet imperfectly, through CLIA's geographically biased figures, accounting only for 70 per cent of the 2002 overall demand for cruising (or more accurately the satisfied demand for cruising, as there is a general consensus in the cruise industry that demand would be higher if there more capacity was offered, as long as it is marketed at the right price). CLIA was founded in the early 1970s and its first reliable estimate amounted to 1.40 million passengers in 1979. The figure rose to 1.85 million in 1984, 3.30 million in 1989, 4.45 million in 1994 and 6.15 million in 1999, meaning more than a fourfold increase in twenty years. It reached 6.9 million passengers in 2000 and 7.40 million in 2001, despite the 9-11 tragedy. This had a big impact on the geography of cruising, with more «homeland cruising» (more sailings from US ports, and less from overseas), but not on the number of cruise passengers. This grew to the above-mentioned 8.60 million in 2002 and to 9.50 million in 2003, with a forecast of about 10.50 million in 2004 (CLIA, 2004).

16 These are impressive figures, but contrarily to our initial hypothesis, the overall rate of expansion of the cruise industry has been somewhat lower, actually, than that of the 
container industry, as measured in both cases through two proxies (namely the traffic of the top 50 container ports and CLIA passengers). Indeed, between 1984 and 2003, the (North American) cruise industry grew by «just» 342 per cent (from 2.15 to 9.5 million passengers), against +477.5 per cent per cent for boxes at the 50 largest container ports of the world (from 35.9 to 207.2 million TEUs). However, the growth as been steady over time for cruise industry, with growth rates of + 107 per cent between 1984 and 1994, and of +113.5 per cent between 1994 and 2003, whereas the pace of the rise has been diminishing somewhat in the recent years for containers, with +151.5 per cent between 1984 and 1994, and + 129.7 per cent between 1994 and 2003.

17 As the average length of cruises is slightly below 7 days, the 10.5 million passengers expected in 2004 by CLIA member lines will translate into about 70 million bed-days (also known as berth-days; this is the most meaningful statistical measure for demand and offer, as in the tourism industry in general; see Israel \& Miller, 1999). If one accepts that CLIA's figures account for about 70 per cent of the worldwide demand, the overall demand can be estimated at about 100 million bed-days in 2004. As shown elsewhere (McCalla \& Charlier, 2004), the overall theoretical offer for the very same year will amount to about 102.5 million bed-nights, meaning a high occupancy rate of the ships, far higher than for onshore tourism. This is because cruise ships are not only floating resorts, but they are also mobile resorts, and cruise lines are therefore able to move their ships worldwide in order to maximize their occupancy rates according to the succession of the seasons.

Overall, North and Central American waters will account for 59 per cent of the effective offer for cruising in 2004 (excluding idle vessels), against 24.5 per cent for Europe and 16.5 per cent for the rest of the world. Within North and Central America, the Caribbean will account for some 41 per cent of the world offer in 2004, but this average yearly figure is not very meaningful, as cruise shipping is a highly seasonal industry; actually, the Caribbean were due to account for 56 per cent in the first quarter, against for just 35 per cent in the second quarter and for 27 per cent in the third quarter, before rising again to 49 per cent in the fourth quarter (ibidem).

19 As most regional markets feature similar seasonal contrasts (in several cases with no offer at all in the winter season), inter- and intraregional ship repositionings are a key factor for the economic success of cruise lines. Some of these voyages, especially CaribbeanAlaska repositiong cruises and round the world cruises, imply compulsory Panama Canal transits on their journey and this is why cruise ships have for a long time strictly adhered to the panamax standards, the more so as many lines have discovered that the canal is a lucrative destination in itself. Nowadays, there are also many regional itineraries featuring the Panama Canal as a strong selling point; these include either full transits between the Atlantic and Pacific oceans, or partial transits for ships entering and leaving the waterway on the same side (usually on the Atlantic side, as an extension of Caribbean cruises).

\section{Two major features of the cruise industry}

Fundamentally, cruise shipping is a branch of the tourism industry, not one of the transport industry (Dickinson \& Vladimir, 1997). It has inherited of the legacy of the great passenger liners, but nowadays the bulk of the ocean-going cruise fleet consists of purpose built vessels. Most of the former liners that had a second lease of life as cruise 
ships have now been scrapped, are idle or are confined to secondary roles (Middlemiss, 1997), with a few major exceptions like the panamax-sized Queen Elizabeth 2 (actually built as a dual purpose ship, namely a transatlantic liner in summer and a cruise ship in winter). Until recently, this was also the case for the Norway, but this overpanamax-sized vessel is currently idle after a major technical incident in 2003 and her future is unclear. She spent the first part of her career on the North Atlantic as the luxury passenger liner France and the second part of it as a mass market cruise ship, sailing in the Caribbean for Norwegian Cruise Line (Durand, 2004). Her former American competitor, the United States, is also idle (but in this case since 1969) and she is reported to be in a very bad condition (Miller, 2003). Nevertheless, Norwegian Cruise Line is planning to rebuild her for the US market; as she is panamax-sized, one of her possible uses as a cruise ship under the US flag (after a total rebuilding) is to offer U-shaped cruises between the Atlantic and Pacific US coasts via the Panama Canal.

21 There is no comprehensive statistical source for the cruise industry and we established therefore our own data base for the analyses offered below, with ShipPax's Guide 2003 as the main source of the vessels' technical and ownership details. This unpublished data base reflects the situation as at 01-01-2003 and includes 230 ocean-going cruise ships (excluding purely coastal and river units) with a passenger capacity of at least 100 lower berths. This is a better statistical unit than the overall number of passengers, including the upper berths in some cabins, if any, because the number of such lower berths shows the number of cabins and, hence, the physical size of the ship. It excludes old vessels idle for some time and with little prospects of sailing again (including the above-mentioned United States, but not the Norway that was still in service at that time), the more so as the latest SOLAS rules for safety at sea are coming into force.

The overall number of lower berths of the said 230 cruise ships amounted to 249,630 and their overall gross tonnage to $9,275,050 \mathrm{gt}$ (gross tons). The gross tonnage is also often referred to in cruise shipping in order to characterize the size of a cruise ship, and both it and the number of lower berths will be used here concurrently, as there is no strict correlation between both measurement units. Actually, their quotient, known as the space ratio, is showing the qualitative level of the ship: the higher the number of gross tons per passenger, the higher the level of comfort and of luxury of the ship. For the whole cruise fleet, it amounted to 37.16, but this world average has little meaning, as there are significant differences between cruise lines, and even between ships within the fleet of a given line.

\section{The overwhelming dominance of a few major players}

In a register of the world cruise fleet, a large number of medium-sized and small cruise lines can be identified, but no real mega player seems to be dominating the market. The largest individual cruise line as at 01-01-2003, namely Royal Caribbean Cruise Line, had only 16 ships in service that is less than 7 per cent of the 230 above-mentioned active vessels. They were accounting for 1,445,100 gt and 37,712 lower berths, and capacity wise this was however 15.6 and 15.1 per cent, respectively, of the two world grand totals for gross tons and lower berths. As can be seen at Table 5, where the fleets in service and on order of the twenty largest individual cruise lines are shown, there was only one line on equal foot with Royal Caribbean Cruise Line, namely Carnival Cruise Lines (it is usually ranking first, actually, and it was due to rank first again in 2004, as it had more ships on 
order). There was a big gap with lines ranking further down capacity wise, like Princess Cruises, Celebrity Cruises, Holland America Line, Norwegian Cruise Line or Costa Crociere, whose fleets in service accounted for between 750,000 and 400,000 gt, with between 18,000 and 10,000 lower berths each.

Table 5. The twenty largest individual cruise lines (situation as at 01-01-2003).

\begin{tabular}{|c|c|c|c|c|c|c|}
\hline & \multicolumn{2}{|c|}{ Ships in service } & \multicolumn{4}{|c|}{ Ships on order } \\
\hline & Ships & $\begin{array}{l}\text { Gross } \\
\text { tonnage }\end{array}$ & $\begin{array}{l}\text { Lower } \\
\text { berths }\end{array}$ & Ships & $\begin{array}{c}\text { Gross } \\
\text { tonnage }\end{array}$ & $\begin{array}{l}\text { Lower } \\
\text { berths }\end{array}$ \\
\hline Royal Caribbean Cruise Line & 16 & $1,445,100$ & 37,712 & 3 & 318,500 & 7,338 \\
\hline Carnival Cruise Lines & 18 & $1,375,600$ & 38,122 & 4 & 416,300 & 11,036 \\
\hline Princess Cruises & 10 & 744,600 & 17.966 & 5 & 550,000 & 13,322 \\
\hline Celebrity Cruises & 9 & 681,050 & 16.450 & - & - & - \\
\hline Holland America Line & 11 & 619,900 & 14,470 & 3 & 252,000 & 5,904 \\
\hline Norwegian Cruise Line & 8 & 599,650 & 17,002 & 1. & 72,000 & 1,900 \\
\hline Costa Crociere & 8 & 408,600 & 10,794 & 3 & 295,700 & 7,550 \\
\hline P\&O Cruises & 4 & 300,300 & 7,682 & - & - & - \\
\hline Star Cruises & 6 & 276,500 & 7,482 & - & - & - \\
\hline Festival Cruises & 6 & 212,600 & 6.459 & - & - & - \\
\hline Disney Cruise Lines & 2 & 166,700 & 3.508 & - & - & - \\
\hline Royal Olympia Cruises & 11 & 136,150 & 5,522 & - & - & - \\
\hline Radisson Seven Seas & 5 & 124,350 & 2,082 & 1 & 46,000 & 720 \\
\hline Sun Cruises & 4 & 100,300 & 4,570 & - & - & - \\
\hline Crystal Cruises & 2 & 99,650 & 1,840 & 1 & 68,000 & 1,096 \\
\hline Cunard Line & 2. & 94,850 & 2,326 & 2. & 226,000 & 4,362 \\
\hline Louis Cruise Line & 7 & 84,600 & 3.787 & - & - & - \\
\hline Aida Cruises & 2 & 80,850 & 1.452 & 1 & 42,300 & 1,266 \\
\hline Mediterranean Shipping Cruises & 3 & 72,050 & 2,537 & 2 & 117,200 & 3,052 \\
\hline Arosa Cruises & 1 & 69,850 & 1,590 & - & - & - \\
\hline
\end{tabular}

COMPUTED FROM SHIPPAX'S GUIDE 2003 (OCEANgOINg VESSELS WITH AT LEAST 100 LOWER BERTHS)

But as for container shipping, many of these cruise lines are part of larger corporate groups, for the very same reasons (search for financial and operational economies of scale, as well as of commercial scope), and the above ranking is therefore misleading. The one shown at Table 6 is much more meaningful, with four major world players on the one hand, and a series of independent lines on the other hand. The largest sixteen of these are identified there (with, at that time, only one grouping among these as far as ownership is concerned, namely between Louis Cruise Line and Royal Olympia Cruises, whose alliance came however recently to an end because of the latter's big financial troubles). 
Table 6. The overwhelming dominance of four large groups on the world cruise market (situation as at 01-01-2003).

\begin{tabular}{|c|c|c|c|c|c|c|}
\hline & \multicolumn{3}{|c|}{ Ships in service } & \multicolumn{3}{|c|}{ Ships on order } \\
\hline & Ships & $\begin{array}{c}\text { Gross } \\
\text { tonnage }\end{array}$ & $\begin{array}{l}\text { Lower } \\
\text { berths }\end{array}$ & Ships & $\begin{array}{c}\text { Gross } \\
\text { tonnage }\end{array}$ & $\begin{array}{l}\text { Lower } \\
\text { berths }\end{array}$ \\
\hline Four largest players & 109 & $7,000,900$ & 182,366 & 22 & $2,176,800$ & 52,678 \\
\hline Carnival Corporation & 46 & $2,560,650$ & 67,070 & 12 & $1,190,000$ & 28,852 \\
\hline Royal Caribbean Group & 26 & $2,166,300$ & 55,674 & 3 & 318,500 & 7,338 \\
\hline P\&O Princess Cruises & 20 & $1,341,450$ & 33,238 & 6 & 596,300 & 14,588 \\
\hline Star Goup & 17 & 932,500 & 26,384 & 1 & 72,000 & 1,900 \\
\hline Independent lines & 121 & $2,274,050$ & 67,264 & 5 & 235,200 & 4,868 \\
\hline \multicolumn{7}{|l|}{ Louis/Royal Olympia } \\
\hline Cruises & 18 & 220,750 & 9,309 & - & - & . \\
\hline Festival Cruises & 6 & 212,600 & 6,459 & - & - & . \\
\hline Disney Cruise Lines & 2 & 166,700 & 3,508 & - & - & - \\
\hline Radisson Seven Seas & 5 & 124,350 & 2,082 & 1 & 46,000 & 720 \\
\hline Sun Cruises & 4 & 100,300 & 4,570 & - & - & - \\
\hline Crystal Cruises & 2 & 99,650 & 1,840 & 1 & 68,000 & 1,096 \\
\hline \multicolumn{7}{|l|}{ Mediterranean Shipping } \\
\hline Cruises & 3 & 72,050 & 2,537 & 2 & 117,200 & 3,052 \\
\hline Thomson (TO's cruise & & & & & & \\
\hline Fred Olsen Lines & $\begin{array}{l}2 \\
3\end{array}$ & $\begin{array}{l}60,400 \\
58,950\end{array}$ & $\begin{array}{l}2,214 \\
1,970\end{array}$ & - & $\begin{array}{c}- \\
-\end{array}$ & . \\
\hline Pullmantur & 2 & 58,950 & 1,696 & - & - & - \\
\hline Hapag-Lloyd & 4 & 58,470 & 1,162 & - & - & - \\
\hline Phoenix Seereisen & 2 & 53,000 & 1,732 & - & - & - \\
\hline Nippon Charter Cruises & 2 & 45,224 & 722 & - & - & - \\
\hline ResidenSea & 1 & 43,188 & 699 & - & - & - \\
\hline Transocean Tours & 2 & 39,200 & 1,002 & - & - & . \\
\hline Saga Holidays & 2 & 36,439 & 955 & - & - & . \\
\hline Other lines & 61 & 823,880 & 24,807 & 1 & 4,000 & 138 \\
\hline Overall & 230 & $9,275,050$ & 249,630 & 27 & $2,412,000$ & 57,546 \\
\hline
\end{tabular}

Computed from ShipPax's Guide 2003 (oceangoing vessels with at least 100 lower berths)

The above-mentioned four major players were, as at 01-01-2003, Carnival Corporation (46 ships, 2,560,650 gt and 67,070 lower berths), the Royal Caribbean Group (26 ships, 2,166,300 gt and 55,674 lower berths), P\&O Princess Cruises (20 ships, 1,341,450 gt and 33,238 lower berths), and the Star Group (17 ships, 932,500 gt and 26,384 lower berths). Together, they accounted for 109 ships, that is slightly less than half of the fleet, but as there were much bigger than average, their combined shares reached 75.5 per cent for gross tonnage $(700,900 \mathrm{gt})$ and 73 per cent for lower berths $(182,366)$. This is a far higher capitalistic concentration degree than in the container industry (as shown above, the four largest container players amounted to just one third of the TEUs for the cellular fleet and to as little as 25.5 per cent of the overall container fleet).

Moreover, the trend is even towards further concentration. On the one hand, as will be seen below in greater details, a mega merger took place early in 2003 between two of these groups and another merger might take place soon or later between the other two, leading to a quasi duopolistic situation (like in the aircraft industry with Airbus and Boeing). And on the other hand, even without those mergers, their combined shares was anyhow due to be higher in the near future as most of the cruise vessels on order were ordered by these said four groups (with 22 ships on order out 27 , for 90 per cent in gross tonnage and 91.5 per cent in lower berths).

Among the medium-sized independent lines, Mediterranean Shipping Cruises (MSC) and Radisson Seven Seas (with, at that time, two vessels on order each) as well as Crystal Cruises (with one vessel) were also due to grow, even if both MSC and Radisson were planning to sell some older, smaller tonnage. Moreover, MSC had the unique opportunity 
of growing further after buying in 2004 two large ships of the bankrupt Festival Cruises, a much cheaper option than buying out this line as a whole, including the goodwill associated with the brand. MSC has also ordered in 2004 two panamax-sized newbuidings, and its fleet will thus develop dramatically in a very short time; however, the cruise division of the MSC group will remain far smaller than its container division.

\section{The high value of cruise brands}

In the container industry, a lot of mergers took place. On the one hand, this has led to the amalgamation of fleets into a combined brand reflecting the previous individual corporate identities (for example, Maersk Sealand, P\&O Nedlloyd, Hanjin / Senator, CMA CGM and Hapag-Lloyd). And on the other hand, one of the two brands has sometimes disappeared (for example, Uniglory into Evergreen, NOL's container division into APL, CMBT into Safmarine). This is because container lines are all selling more or less the same standard product, and brands are therefore of less value than in the cruise shipping industry, where they reflect a strong regional anchorage. Moreover, at least within the largest three groups, they reflect significant qualitative differences (shown for example in the Berlitz Guide to Cruise Shipping by a rating system from one to five stars). However, some subsidiaries have kept until now a distinct identity with large container groups, like Safmarine within AP Moller or Lloyd Triestino versus Evergreen, and there is one major exception with CP Ships that remains a constellation of individual lines (with some slot exchanges, however).

As can be seen at Table 7, there were, as at 01-01-2004, no less than nineteen individual brands within the four largest groups of cruise lines. In all cases, the main lines are positioned, qualitatively, in the middle of the upper tier of the market, and they have either sister brands at the same qualitative level in another region or distinct brands positioned in another, upper or lower tier of the market. For example, within the Carnival Cruise group, Carnival Cruise Lines and Costa Crociere are positioned on the same qualitative level, but their main markets are North America and Europe, respectively. Whereas within the Royal Caribbean group, whose main market is North America with Europe as a secondary market, Celebrity Cruises are positioned at a higher level than Royal Caribbean Cruise Line. A combination of the two strategies was characterizing both the Carnival Corporation and P\&O Princess Cruises before their recent merger, whereas a merger between the Royal Caribbean and Star groups could be supported by the same combined strategy of brand positioning. In the recent history of cruise shipping, there has been only four exceptions to this general trend of keeping the individual identities of the lines being bought, namely for Home Lines merged into Holland America Line, for Admiral Cruises merged into Royal Caribbean Cruise Line, for Royal Cruise Line merged into Norwegian Cruise Line, and for Sitmar Cruises merged into Princess Cruises. However other lines have disappeared, either because they were closed down by their owners (such as Royal Viking Line at the time it was a sister company of Norwegian Cruise Line) or because they went into bankruptcy (like Premier Cruises, Renaissance Cruises or more recently Festival Cruises). 
Table 7. The fleet of the four largest cruise groups and of their brands as at 01.01.2003.

\begin{tabular}{|c|c|c|c|c|c|c|}
\hline & \multicolumn{3}{|c|}{ Ships in service } & \multicolumn{3}{|c|}{ Ships on order } \\
\hline & Ships & $\begin{array}{c}\text { Gross } \\
\text { tonnage }\end{array}$ & $\begin{array}{l}\text { Lower } \\
\text { borths }\end{array}$ & $\begin{array}{c}\text { Ships } \\
-\end{array}$ & $\begin{array}{c}\text { Gross } \\
\text { tonnage }\end{array}$ & $\begin{array}{l}\text { Lower } \\
\text { berths }\end{array}$ \\
\hline Carnival Corporation & 46 & $2,560,650$ & 67,070 & 12 & $1,190,000$ & 28,852 \\
\hline Carnival Cruise Lines & 18 & $1,375,600$ & 38,122 & 4 & 416,300 & 11,036 \\
\hline Costa Crociere & 8 & 408,600 & 10,784 & 3 & 295,700 & 7,550 \\
\hline Holland America Line & 11 & 619,900 & 14,470 & 3 & 252,000 & 5,904 \\
\hline Cunard Line & 2 & 94,850 & 2,326 & 2 & 226,000 & 4,362 \\
\hline Seabourn Cruise Line & 3 & 29,850 & 612 & - & - & - \\
\hline Windstar Sail Cruises & 4 & 31,850 & 756 & - & - & - \\
\hline Royal Caribbean Group & 26 & $2,166,300$ & 56,674 & 3 & 318,500 & 7,338 \\
\hline Royal Caribbean Cruise Line & 16 & $1,445,100$ & 37,712 & 3 & 318,500 & 7,338 \\
\hline Celebrity Cruises & 9 & 681,050 & 16,450 & - & - & - \\
\hline Island Cruises (joint venture) & 1 & 40,150 & 1,512 & - & - & - \\
\hline P\&O Princess Cruises & 20 & $1,341,450$ & 33,238 & 6 & 596,300 & 14,588 \\
\hline Princess Cruises & 10 & 744,600 & 17,996 & 5 & 550,000 & 13,322 \\
\hline P\&O Cruises & 4 & 300,300 & 7,682 & & - & \\
\hline Other British brands (three) & 3 & 145,850 & 3,538 & - & - & . \\
\hline German brands (two) & 3 & 150,700 & 4,042 & 1 & 42,300 & 1,266 \\
\hline Star Group & 17 & 932,500 & 26,384 & 1 & 72,000 & 1,900 \\
\hline Star Cruises & 6 & 276,500 & 7,482 & - & - & $=$ \\
\hline Norwegian Cruise Line & 8 & 599,650 & 17,002 & 1 & 72,000 & 1,900 \\
\hline Orient Line & 2 & 56,350 & 1,900 & - & - & - \\
\hline
\end{tabular}

COMPUTED FROM SHIPPAX'S GUIDE 2003 (OCEANgOINg VESSELS WITH AT LEAST 100 LOWER BERTHS)

As at 01-01-2003, the Carnival Corporation was the largest of the four major groups, with six well established brands. Carnival Cruise Lines is positioned at the upper tier of the mass market in North America and Costa Crociere is at the same qualitative level in Europe; Holland America Line is a premium line whose main market is North America but with worldwide operations; Cunard Line is a luxury line for North Americans and Europeans and with two niche market operations using mega yacht-sized ships. These are Seabourn Cruise Line for the luxury market and Windstar Sail Cruises for, as its name implies, unconventional cruises under sail, aimed at the premium market; in both cases, most of their guests are drawn from North America. These two niches are marginal, however, and they will be even more in the future, as there were no ships on order for them (but ClubMed 2 could perhaps be bought by Carnival for Windstar, as ClubMed 1, now Wind Surf, has already been), and as there will be a dilution effect with the recent merger between Carnival Corporation and P\&O Princess Cruises.

31 The structure of the Royal Caribbean Group is much simpler, with the main brand (Royal Caribbean Cruise Line) positioned between the mass market and the premium segment, and with another strong brand (Celebrity Cruises) at the upper tier of the said premium market. In both cases, North American passengers are the more numerous, but there is also a new European joint-venture (Island Cruises) for the European mass market. Currently, all of the ships on order are for the main line, whose relative importance within the group will therefore increase further.

Before it merged, early in 2003, with the Carnival Corporation, P\&O Princess Cruises were themselves the product of the takeover of the US-based Princess Cruises, positioned on the same qualitative segment as Royal Caribbean Cruise Line, and of the cruise shipping 
branch of the P\&O Group. The latter was featuring a series of brands, each targeted at a specific segment, with the main line (P\&O Cruises) positioned qualitatively as Princess Cruises but with a strong British flair, and a series of five highly specific brands. On the one hand, there are three brands for the British or Australian markets, namely Ocean Village (a new club-style operation for British guests), P\&O Holidays (mass market cruises for Australians), and Swan Hellenic (cultural cruises for British passengers). And on the other hand, there were at that time two different German brands (marketed under the umbrella of Seetours), a conventional product (Arosa) and a club ship operation (Aida).

P\&O Princess Cruises was the group where the advantages of a group structure were the more visible in the optimal deployment of the fleet, thanks to a series of internal transfers. Two of them took place from Princess Cruises to P\&O Cruises (a horizontal transfer, qualitatively speaking), one from Princess Cruises to P\&O Holidays (a vertical transfer), one from Princess Cruises to Arosa (a diagonal transfer) and one from Princess Cruises to P\&O Cruises, then to Ocean Village (a horizontal followed by a vertical transfer). Another series of transfers took place in 2003 and 2004 after the merger with Carnival Corporation, including reverse transfers, and a reshuffle took place on the German market where Arosa merged into Aida; however, Costa Crociere, now a sister company, has kept under its own umbrella one ship specially aimed at this market, what is strategically questionable in a corporate perspective.

By contrast, within the larger Carnival Corporation empire, such internal moves took place only three times before the said merger, from Carnival Cruise Lines to Costa Crociere (a horizontal transfer), from Holland America Line to Costa Crociere (a vertical transfer) and from Seabourn to Holland America Line (also a vertical transfer). And except for transferring one ship from the main line to the above-mentioned new European joint venture (horizontally and vertically), this did not happen within the Royal Caribbean Group.

On the contrary, such transfers have been quite common within the fourth major player, namely the Star group, where two new buildings ordered for the Malaysian parent, Star Cruises, were redirected before entering in service to its American subsidiary, Norwegian Cruise Lines, because of the changing conditions on the Asian market. Star's (over)ambitious expansion plans could be elegantly scaled down there thanks to lastminute transfers before the ships were delivered (implying some internal adaptations but no significant extra cost). Moreover, Star's two previous new buildings have recently gone to Norwegian Cruise Line, in one case in the context of an exchange of vessels, showing another example of flexible fleet adaptations within a group of cruise lines.

Even if Star Cruises is the mother company, the main line within the Star Group is currently its US subsidiary, Norwegian Cruise Line. Star Cruises' fleet is more disparate and this is the line where there were the more numerous "come-and-go» in the fleet in the last few years, with only two new buildings in service as at 01-01-2003, and no vessel on order after the second series of two were actually delivered to Norwegian Cruise Line. There is also a third line in the group, Orient Line, aimed at North American and European guests, a two-ship operation as at the end of 2002 but with one of the two vessels going back thereafter to Norwegian Cruise Line in another example of reverse horizontal transfer. This group is the only one with a new brand currently in the pipeline, to be called NCL America, with US-flagged and US-crewed vessels to operate on the Hawaii market after the bankruptcy of American Hawaii Cruise Lines, with a fleet including up to two reflaged existing foreign vessels, two new buildings ordered by a 
previous, now bankrupt operator and perhaps the former transatlantic liner United States, if she undergoes a total rebuilding after being laid-up for thirty-five years.

\section{Carnival Corporation/plc as the new industry leader}

37 As mentioned above, the first and third largest players in the cruise industry merged in April 2003.Technically, it has taken the form of a takeover of P\&O Princess Cruises by Carnival Corporation through the formula of a dual-listed company, with Carnival Corporation quoted in New York on the NYSE and Carnival plc quoted in London on the LSE (with about 80 and 20 per cent, respectively, of the market capitalization). The impressive domination of the new giant can be seen at Table 8 , where their combined fleets amounted, as retroactively at $01-01-2003$, to 66 vessels (that is 28.5 per cent of the world fleet), with 3,902,100 gt and 100,308 lower berths (that is, respectively, 42.0 and 40.2 per cent of the world grand totals). The said domination will be even higher in the near future, as most of the ships on order (18, for another 1,782,300 gt and 43,300 lower berths) will go to the lines of a new giant sometimes referred to as Carnivore Cruise Lines. This should be compared to the 13 per cent of the cellular fleet and the 10 per cent of the whole container fleet shown above for the container industry leader, the AP Moller Group.

Table 8. From four to three (then two?) large cruise groups (situation as at 01-01-2003).

\begin{tabular}{|c|c|c|c|c|c|c|}
\hline & \multicolumn{3}{|c|}{ Ships in service } & \multicolumn{3}{|c|}{ Ships on order } \\
\hline & Ships & $\begin{array}{c}\text { Gross } \\
\text { tonnage }\end{array}$ & $\begin{array}{l}\text { Lower } \\
\text { berths }\end{array}$ & Ships & $\begin{array}{l}\text { Gross } \\
\text { tonnage }\end{array}$ & $\begin{array}{l}\text { Lower } \\
\text { berths }\end{array}$ \\
\hline \multicolumn{7}{|l|}{ Situation at $01-01-2003$} \\
\hline Carnival Corporation & 46 & $2,560,650$ & 67,070 & 12 & $1,190,000$ & 28,852 \\
\hline Royal Caribbean Group & 26 & $2,166,300$ & 55,674 & 3 & 318.500 & 7,338 \\
\hline P\&O Princess Cruises & 20 & $1,341,450$ & 33,238 & 6 & 592,300 & 14,588 \\
\hline Star Group & 17 & 932,500 & 26,384 & 1 & 72,000 & 1,900 \\
\hline \multicolumn{7}{|l|}{ Initial merger proposal } \\
\hline Royal Caribbean / P\&OPC & 46 & $3,507,750$ & 88,912 & 9 & 910,800 & 21,976 \\
\hline Carnival Corporation & 46 & $2,560,650$ & 67,070 & 12 & 1.190 .000 & 28,852 \\
\hline Star Group & 17 & 932.500 & 26,384 & 1 & 72,000 & 1.900 \\
\hline \multicolumn{7}{|l|}{ Possible countermerger (1) } \\
\hline Royal Caribbean / P\&OPC & 46 & $3,507,750$ & 88,912 & 9 & 910,800 & 21,976 \\
\hline Carnival/Star & 63 & 3.466 .285 & 93,454 & 13 & $1,262,000$ & 30,752 \\
\hline \multicolumn{7}{|l|}{ Current merger } \\
\hline Carnival Corporation/plc & 66 & $3,902,100$ & 100,308 & 18 & $1,782,300$ & 43,440 \\
\hline Royal Caribbean Group & 26 & $2,166,300$ & 55,674 & 3 & 318,500 & 7,338 \\
\hline Star Group & 17 & 932,500 & 26,384 & 1 & 72,000 & 1.900 \\
\hline \multicolumn{7}{|l|}{ Possible countermerger (2) } \\
\hline Carnival Corporation / plc & 66 & $3,902,100$ & 100,308 & 18 & $1,782,300$ & 43,440 \\
\hline Royal Caribbean / Star & 43 & $3,098,800$ & 82,058 & 4 & 390,500 & 9,239 \\
\hline
\end{tabular}

For many industry observers, it has been hard to understand how the US, European and British antitrust authorities gave their green light to such a mega merger, the more so as Carnival Corporation/plc will find itself in a situation of absolute domination on some key markets. This has been especially the case in Alaskan waters, with 14 ships for four of its brands in the 2003 summer season (for 847,000 gt and 20,094 lower berths) against only 10 ships (excluding coastal vessels) for five competing lines (for 724,650 gt and 17,475 lower 
berths). This even less understandable as Holland America Line and Princess Cruises are there in an overwhelming position ashore (at least 80 per cent) thanks to their respective subsidiaries Westours and Princess Tours. These offer highly popular packages combining cruises and pre- or post-cruise tours in Alaska, including by train, for which they own the whole fleet of panoramic railroad equipment. Strangely enough, Carnival Corporation/plc has been given the green line without even being obliged to disinvest somewhat in Alaska in order to keep there a reasonable degree of competition. One of the reasons given by the antitrust bodies (and by Carnival/Princess in their application) is that the main competition is not between individual cruise lines or cruise groups, but between the cruise industry as a whole and other forms of tourism. It remains to be seen if they were right and if Carnival Corporation/plc will be tempted in the future to abuse of its dominant position.

Actually, the initial merger proposal came from the Royal Caribbean Group and it had first the favour of P\&O Princess Cruises' management. It would have lead to a much more balanced situation, with 46 ships each for Carnival Corporation in its original definition and for the Royal Caribbean / P\&O Princess combination. This would have ranked first, with 3,507,750 gt and 88,912 lower berths, against 2,560,650 gt and 67,070 lower berths for Carnival Corporation, but the imbalance could have been easily rectified as Carnival had more capacity on order and as it had the financial means available to merge with another player. For example, a merger with the Star Group would have lead with a quasi perfectly balanced duopolistic situation, capacity wise $(3,466,300$ and 93,454 lower berths for a Carnival / Star combination, against 3,507,750 gt and 88,912 lower berths for the Royal Caribbean / P\&O Princess combination). To counterbalance the new Carnival Corporation/plc galaxy, the only solution left in the short term is a Royal Caribbean / Star combination, but such a merger would lead to a slightly less powerful counterweight in the short term $(3,098,800 \mathrm{gt}$ and 82,058 lower berths) and to an increased gap after the ships currently on order are delivered.

Such a situation would have never been allowed to happen in the container shipping or in the airline industries, and one still wonder why, at least, some significant divestures were not even asked for, especially by the US authorities. For example, breaking P\&O Princess Cruises into two parts, with only its European brands joining Carnival Corporation and Princess Cruises being offered for sale to Star Cruises, would have led to a much more balanced situation. There would have been then three large players on more or less equal foot and with no major qualitative and geographic overlap between their brands, as it is now the case with Holland America Line and Princess Cruises within Carnival Corporation/plc (not only in Alaska in summertime, but also in Europe at that time and in the Caribbean in winter).

\section{The increasing share of panamax and overpanamax cruise ships}

41 The cruise industry has entered into the panamax and overpanamax eras, for the very same reasons (search for economies of scale) but much later than container shipping. As Table 9 shows, out of the 230 cruise vessels in service as at 01-01-2003, 157 were infrapanamax-sized (namely with a beam of less than 100 feet or 30.5 meters, as defined by the Panama Canal Authority). However, there were 61 panamax-sized vessels (with a beam up to 32.3 meters) and already 12 were overpanamax-sized (with a beam above 32.3 meters, currently up to 41.0 meters for Cunard's Queen Mary 2 delivered at the end of 
2003). In the latter two categories, two special, older ships built as transatlantic liners are included, namely Cunard's Queen Elizabeth 2 on the one hand and Norwegian Cruise Line's Norway on the other hand (currently idle after a technical incident). Both were built in the 1960s, whereas all the other large and very large cruise ships were purely built for cruising, as many of the smaller vessels but much later than these. This is simply because it would have been commercially impossible to fill ships with more than, say, 2,000 passengers before cruise shipping had become a mature industry with a rather large customer base, first on the North American market, then in Europe and more globally.

Table 9. Structure of the world cruise fleet in service as at 01-01-2003 by gross tonnage classes.

\begin{tabular}{|c|c|c|c|c|c|c|}
\hline & $\begin{array}{c}\text { Carnival } \\
\text { Corporation: }\end{array}$ & $\begin{array}{c}\text { Royal } \\
\text { Caribbean }\end{array}$ & $\begin{array}{c}\text { P\&O } \\
\text { Princess }\end{array}$ & $\begin{array}{l}\text { Star } \\
\text { Group }\end{array}$ & $\begin{array}{l}\text { Other } \\
\text { lines }\end{array}$ & $\begin{array}{l}\text { Grand } \\
\text { total }\end{array}$ \\
\hline fnfrapanarnax & 19 & 3 & 7 & 10 & 119 & 158 \\
\hline$<20,000$ & 7 & - & - & 1 & 75 & 83 \\
\hline $20,000-39,999$ & 6 & - & 4 & 4 & 37 & 51 \\
\hline $40,000-59,999$ & 6 & 3 & 3 & 5 & 7 & 24 \\
\hline Panamax & 23 & 19 & 10 & 6 & 2 & 60 \\
\hline$<60,000$ & 5 & 1 & - & - & - & 6 \\
\hline$\infty 0,000-79,999$ & 13 & 12 & 9 & 4 & 2 & 40 \\
\hline $80,000-99,999$ & 5 & 6 & 1 & 2 & - & 14 \\
\hline Overpanamax & 4 & 4 & 3 & 1 & - & 12 \\
\hline$<100,000$ & - & - & - & 1 & - & 1 \\
\hline $100,000-119,999$ & 4 & - & 3 & - & - & 7 \\
\hline $120,000-139,999$ & - & 4 & - & - & - & 4 \\
\hline$\geq 140,000$ & - & - & - & - & - & - \\
\hline Overall & 46 & 26 & 20 & 17 & 121 & 230 \\
\hline
\end{tabular}

Computed from ShipPax's Guide 2003

42 As can be seen at Figure 2, the first purpose-built panamax-sized cruise ship (Royal Caribbean Cruise Line's Sovereign of the Seas) entered in service only in 1987, and this segment of the cruise fleet grew steadily since then, with a first maxipanamax (a special category, for which the length is the maximum accepted in the Panamax locks, namely 294.0 meters, as this was already the case for Queen Elizabeth 2) joining the fleet in 1998 (Disney Cruise Lines' Disney Magic). Actually, the latter came into service after the first purpose-built overpanamax, which entered in service in 1996 (Carnival Cruise Lines' Carnival Destiny), as cruise lines saw first the benefits of going overpanamax in terms of economies of scale. However, they realized quickly that they also needed, for part of their fleet, the flexibility offered by the panamax design, optimized nowadays to more than 90,000 gt and perhaps up to 100,000 gt in the Finnish Nova project). Moreover, very few standard panamax cruise ships were built recently, and only one was on order in early 2003 (four more followed since that time, however); this is also the case for container shipping where the panamax design has been gradually improved to vessels of more than 4,000 TEUs of maxipanamax standard (also known as panamax-max). 
Figure 2. The rise of the panamax- and overpanamax-sized cruise fleet (number of ships).

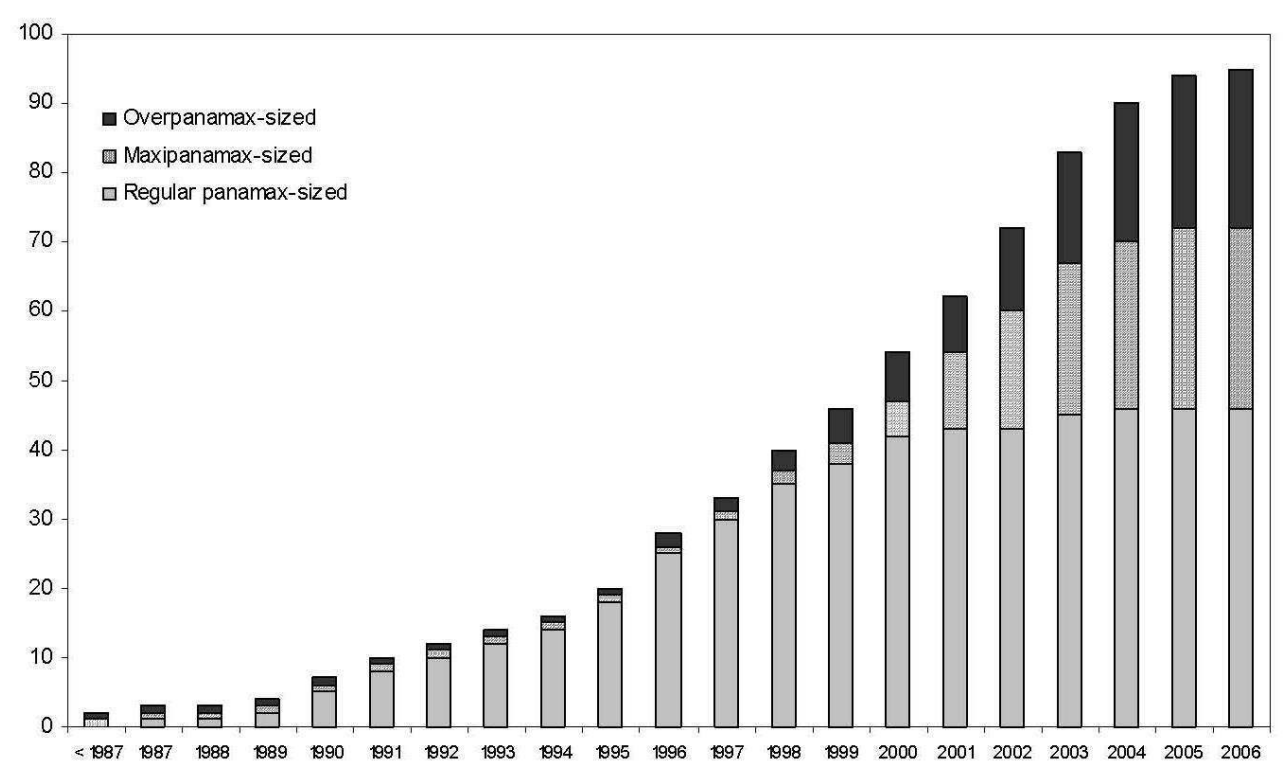

What is unique to the cruise industry is that virtually all of the large or very large cruise ships in service (Table 9) or on order (Table 10) are or will be operated by lines part of the four above-mentioned dominant groups (three nowadays, after the Carnival/Princess merger). As at 01-01-2003, there were 23 panamaxes and 4 overpanamaxes in service within the Carnival Corporation fleet (plus another 6 and 6 on order), and the figures were $19+4$ (and $2+1$ ) for the Royal Caribbean Group, $10+3$ (and $1+4$ ) for the then independent $\mathrm{P} \& \mathrm{O}$ Princess Cruises, and $6+1$ (but only $1+0$ ) for the Star Group (excluding the planned conversion of the maxipanamax-sized United States). The latter group was clearly behind its rivals in the recent search for economies of scale, and its fleet still featured a majority of infrapanamax-sized vessels (10 out of 17 , including three ships that were lengthened in order to be more productive). On the contrary, infrapanamaxes were already less numerous than the other two, larger categories in the fleets in service of Carnival Corporation (19 out of 46, including 7 very small ships for its two niche market brands); this was also the case for the Royal Caribbean Group (only 3 left out of 26, after most of its smaller tonnage was sold) and for P\&O Princess ( 7 out of 20). At that time, the four major players have only one infrapanamax-sized ship on order (for P\&O Princess Cruises' German brand Aida), showing how far they have gone into the race for ever bigger ships. However, they still have the possibility to turn to the second hand market when they need smaller vessels for specific niche markets, as was the case recently for three of the former Renaissance mid-sized ships, two of which went to Princess Cruises and one to Swan Hellenic. 
Table 10. Structure of the world cruise fleet on order as at 01-01-2003 by gross tonnage classes.

\begin{tabular}{lcccccc}
\hline & $\begin{array}{c}\text { Carnival } \\
\text { Corporation }\end{array}$ & $\begin{array}{c}\text { Royal } \\
\text { Caribbean Princess }\end{array}$ & $\begin{array}{c}\text { P\&O } \\
\text { Group }\end{array}$ & $\begin{array}{c}\text { Other } \\
\text { lines }\end{array}$ & $\begin{array}{c}\text { Grand } \\
\text { total }\end{array}$ \\
\hline $\begin{array}{l}\text { Infrapanamax } \\
<20,000\end{array}$ & - & - & 1 & - & 4 & 5 \\
$20,000-39,999$ & - & - & - & - & 1 & 1 \\
$40,000-59,999$ & - & - & - & - & - & - \\
$\begin{array}{l}\text { Panamax } \\
<60,000\end{array}$ & 6 & 2 & 1 & - & 3 & 4 \\
$60,000-79,999$ & - & - & - & - & 1 & 11 \\
$80,000-99,999$ & 6 & - & - & 1 & 1 & 2 \\
$\begin{array}{l}\text { Overpanamax } \\
<100,000\end{array}$ & 6 & - & 1 & - & - & 9 \\
$100,000-119,999$ & -5 & - & - & - & - & 11 \\
$120,000-139,999$ & - & 1 & - & - & - & 9 \\
$\geq 140,000$ & 1 & - & - & - & - & 1 \\
\hline Overall & 12 & 3 & 6 & 17 & 5 & 27 \\
\hline
\end{tabular}

COMPUTED FROM SHIPPAX'S GUIDE 2003

\section{Overpanamax-sized ships' ownership}

44 When going into the detailed structure of the four groups by brand, one sees at Table 11 that, in early 2003, overpanamaxes were operated only by the largest brand in each group, namely Carnival Cruise Lines for Carnival Corporation, Royal Caribbean Cruise Lines for the Royal Caribbean Group, Princess Cruises for P\&O Princess Cruises and Norwegian Cruise Line for the Star Group. This will not change in the near future for the latter three groups (as Star Cruises has dropped its plans to enter into the overpanamax era), but overpanamax-sized vessels will be spreading within the Carnival Corporation (now Corporation/ plc).This will be the case at Costa Crociere (with carbon copies, except for the funnels, of Carnival Cruise Lines' giants, in a clear search for intragroup economies of scope) and at Cunard Line, with the already mentioned Queen Mary 2. 
Table 11. Structure of the fleets of the four largest cruise groups as at 01-01-2003 by brand and ship size.

\begin{tabular}{|c|c|c|c|c|c|c|}
\hline & \multicolumn{3}{|c|}{ Ships in service } & \multicolumn{3}{|c|}{ Ships on order } \\
\hline & $\begin{array}{l}\text { Inira- } \\
\text { panamax }\end{array}$ & Panamax & $\begin{array}{l}\text { Over- } \\
\text { panamax }\end{array}$ & $\begin{array}{l}\text { Inira- } \\
\text { panamax }\end{array}$ & Panamax & $\begin{array}{c}\text { Over- } \\
\text { panamax }\end{array}$ \\
\hline Carnival Corporation & 19 & 23 & 4 & - & 6 & 6 \\
\hline Carnival Cruise Lines & 3 & 11 & 4 & - & 1 & 3 \\
\hline Costa Crociere & 6 & 2 & 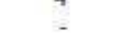 & 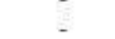 & 1 & 2 \\
\hline Holland America Line & 2 & 9 & - & - & 3 & - \\
\hline Cunard Line & 1 & 1 & - & - & 1 & 1 \\
\hline Seabourn Cruise Line & 3 & - & - & - & - & - \\
\hline Windstar Sail Cruises & 4 & - & - & - & $\therefore$ & - \\
\hline $\begin{array}{l}\text { Royal Caribbean Group } \\
\text { Royal Caribbean Cruise }\end{array}$ & 3 & 19 & 4 & - & 2 & 1 \\
\hline Line & - & 12 & 4 & - & 2 & 1 \\
\hline Celebrity Cruises & 2 & 7 & - & - & - & - \\
\hline Island Cruises (JV) & 1 & - & - & - & - & - \\
\hline P\&O Princess Cruises & 7 & 10 & 3 & - & 1 & 4 \\
\hline Princess Cruises & 3 & 4 & 3 & - & 1 & 4 \\
\hline P\&O Cruises & - & 4 & - & - & - & - \\
\hline Other British brands & & & & & & \\
\hline (three) & 2. & 1 & - & - & - & - \\
\hline German brands (two) & 2 & 1 & - & 1 & - & - \\
\hline Star Group & 10 & 5 & 1 & - & 1 & - \\
\hline Star Cruisos & 4 & 3 & 1 & - & 1 & - \\
\hline Norwegian Cruise Line & 4 & 2 & - & - & - & - \\
\hline Orient Line & 2 & . & - & - & - & - \\
\hline
\end{tabular}

Computed from ShipPax's Guide 2003

45 At $148,528 \mathrm{gt}$, the QM2 is currently the largest cruise ship in service at 148528 gt. This will not last for long, however, as Royal Caribbean Cruise Line has ordered recently a 158,000 gt mega ship (3,600 lower berths) for delivery in 2006 (with another in option, and probably more in the pipeline). Moreover, Carnival Corporation/plc is said to want to keep the leadership with a planned series of 180,000 giants for Carnival Cruise Lines and for Princess Cruises (sharing a same hull but with different standards of accommodations to reflect the different qualitative positioning of the two cruise lines). Excluding these yet to be confirmed plans and planned repeat orders of current, smaller overpanamaxes for the same two lines, Table 12 shows the state of the overpanamax-sized cruise fleet as at 01-07-2004. 
Table 12. Overpanamax-sized cruise ships delivered or on order by cruise line as at 01-07-2004.

\begin{tabular}{|c|c|c|c|c|c|}
\hline & $\begin{array}{l}\text { Year } \\
\text { built }\end{array}$ & $\begin{array}{l}\text { Gross } \\
\text { tonnage }\end{array}$ & $\begin{array}{l}\text { Length } \\
(\mathrm{m})\end{array}$ & $\begin{array}{c}\text { Beam } \\
(\mathrm{m})\end{array}$ & $\begin{array}{l}\text { Lower } \\
\text { berths }\end{array}$ \\
\hline \multicolumn{6}{|l|}{ Carnival Cruise Lines } \\
\hline Carnival Destiny & 1996 & 101,350 & 272.2 & 35.5 & 2,642 \\
\hline Carnival Triumph & 1999 & 101,500 & 272.2 & 35.5 & 2,758 \\
\hline Carnival Victory & 2000 & 101,500 & 272.2 & 35.5 & 2,640 \\
\hline Carnival Conquest & 2002 & 110,200 & 290.2 & 35.5 & 2,974 \\
\hline Carnival Glory & 2003 & 110,200 & 290.2 & 35.5 & 2,974 \\
\hline Carnival Valor & 2004 & 110,200 & 290.2 & 35.5 & 2,974 \\
\hline Carnival Liberty & 2005 & 110,200 & 290.2 & 35.5 & 2,974 \\
\hline \multicolumn{6}{|l|}{ Costa Crociere } \\
\hline Costa Fortuna & 2003 & 105,000 & 272.2 & 35.5 & 2,718 \\
\hline Costa Magica & 2004 & 105,000 & 272.2 & 35.5 & 2,718 \\
\hline Costa TBN (to be named) & 2006 & 110,200 & 290.2 & 35.5 & 3,004 \\
\hline \multicolumn{6}{|l|}{ Cunard Line } \\
\hline Queen Mary 2 & 2003 & 148,500 & 345.0 & 41.0 & 2,514 \\
\hline \multicolumn{6}{|l|}{ Princess Cruises } \\
\hline Grand Princess & 1998 & 108,800 & 289.0 & 36.0 & 2,600 \\
\hline Golden Princess & 2001 & 108,800 & 289.0 & 36.0 & 2,592 \\
\hline Star Princess & 2002 & 108,800 & 289.0 & 36.0 & 2,592 \\
\hline Caribboan Princess & 2004 & 120,000 & 289.0 & 36.0 & 3,000 \\
\hline Sapphire Princess & 2004 & 113,000 & 290.0 & 37.5 & 2,674 \\
\hline Diamond Princess & 2005 & 113,000 & 290.0 & 37.5 & 2,674 \\
\hline Crown (?) Princess & 2006 & 120,000 & 289.0 & 36.0 & 3,000 \\
\hline \multicolumn{6}{|l|}{ Royal Caribbean Cruise Line } \\
\hline Voyager of the Seas & 1999 & 137,300 & 311.1 & 38.6 & 3,138 \\
\hline Explorer of the Seas & 2000 & 137,300 & 311.1 & 38.6 & 3,114 \\
\hline Adventure of the Seas & 2002 & 137,300 & 311.1 & 38.6 & 3,138 \\
\hline Navigator of the Seas & 2002 & 138,300 & 311.1 & 38.6 & 3,138 \\
\hline Mariner of the Seas & 2003 & 138,300 & 311.1 & 38.6 & 3,138 \\
\hline UltraVoyager (project name) & 2006 & 158,000 & 339,0 & 38.6 & 3,600 \\
\hline \multicolumn{6}{|l|}{ Norwegian Cruise Line } \\
\hline Norway (currently idle) & 1961 & 76,050 & 315.5 & 33.7 & 2,122 \\
\hline
\end{tabular}

Sources: ShipPax's Guide 2004 and Cruise Ferry Info 2004/7

To a much higher degree than for the container industry, there is a clear trend for the major lines to order long series of sister ships or of nearly sister ships for the same brand or across brands, horizontally (Carnival/Costa) or even vertically (Carnival/Princess). Currently, the longest series of identical hulls has been for eight standard panamaxes for Carnival Cruise Lines. However, when all ships on order will be delivered, the longest series will be one of ten overpanamaxes for the same line (seven) and for Costa Crociere (three); a figure that could even extend to twelve or thirteen (another two for Carnival, plus one for Costa). There is also a current series of five large overpanamaxes for Royal Caribbean Cruise Line (plus at least two in the pipeline, as the Ultra Voyagers are lengthened versions) and another one of five smaller overpanamaxes for Princess Cruises (another two have been ordered recently at the same yard, whereas two rather similar ships with a somewhat different hull, built in another yard; are not included). And for maxipanamaxes, the same trend is being observed with a series of six vessels either for Carnival Cruise Lines (four) or for Costa Crociere (two), with a series of five ships for Holland America Line and with two different series of four identical vessels for Royal Caribbean Cruise Line and for Norwegian Cruise Line (in this case, with two initial orders for Star Cruises transferred to NCL before delivery and a recent order of two quasi sisters directly for NCL).

Except for two overpanamaxes of a different design built for Princess Cruises in Japan (where a few infrapanamaxes have also been built), all these large cruise ships have been built or are on order at European yards. These have managed to keep a dominant position for these sophisticated vessels, whereas most of the containerships are currently built in Asia (except for some of Maersk Sealand ships, built at AP Moller's Danish yard), be it in 
Japan or in South Korea, whereas Chinese yards are also planning to enter into the race. The European leading builders are Fincantieri in Italy, Kvarner Masa-Yards in Finland, Alstom / Chantiers de l'Atlantique in France and Meyer Werft in Germany, but in the latter two cases the order books are not as strong as what they were previously, and some consolidation might arise as a consequence. Only Fincantieri has a solid order book, but all the ships it will deliver in the next few years will go to the new giant Carnival Corporation/plc, incorporating P\&O Princess Cruises. In the near future, this mega customer could try to split its orders between two or three shipbuilders in order to introduce competition between its suppliers. It remains to be seen if, like this has already happened for the cruise groups, a concentration process will not also take place soon in the European shipbuilding industry. This would also lead to an even smaller number of players on the shipbuilding side, to counterbalance the likely rise of Asian shipbuilders.

\section{Overpanamax-sized ships' operational constraints}

The main reason for the cruise lines to refrain, until the mid-1990s, from ordering overpanamax cruise ships is that they saw total operational flexibility on a seasonal basis as a key criterion of their success. The main geographic complementarity was (and is still) between the Caribbean basin in wintertime and Alaska in summertime (Miller \& Grazier, 2004), but there are also two minor, but highly lucrative markets requiring panamaxsized ships, transcanal cruises on the one hand (Charlier, 2000b) and round the world cruises on the other hand (McCalla \& Charlier, 2004). Like Norway since the early 1980s, the first new overpanamaxes started their commercial life by staying year-round in the Caribbean, but their owners found thereafter new geographic and seasonal complementarities for their very large vessels on each side on the Panama canal, the current pattern of which is shown at Table 13. On the Atlantic side, some ships spend or will spend the summer season either in Europe (mainly the Mediterranean, but also Northern Europe) or in the North East Atlantic out of New York (Klein, 2003) before coming back in the Caribbean for winter, whereas on the Pacific side they are deployed in Alaska in summer and spend wintertime either on the Mexican Riviera or in Asia, after offering a transpacific cruise (Douglas \& Douglas, 2004). 
Table 13. Overpanamax-sized cruise ships cruise areas in 2004-2005.

\begin{tabular}{|c|c|c|}
\hline & Summer season 2004 & Winter season 2004-2005 \\
\hline \multicolumn{3}{|l|}{ Carnival Cruise Lines } \\
\hline Carnival Destiny & Caribbean & Caribbean \\
\hline Carnival Triumph & Caribbean & Caribbean \\
\hline Carnival Victory & NE Atlantic & Caribbean \\
\hline Carnival Conquest & Caribbean & Caribbean \\
\hline Carnival Glory & Caribbean & Caribbean \\
\hline Carnival Valor & Not delivered yet & Caribbean \\
\hline \multicolumn{3}{|l|}{ Costa Crociere } \\
\hline Costa Fortuna & Mediterranean & Mediterranean \\
\hline Costa Magica & Not delivered yet & Mediterranean \\
\hline \multicolumn{3}{|l|}{ Cunard Line } \\
\hline Queen Mary & Transatlantic (mainly) & Worldwide \\
\hline \multicolumn{3}{|l|}{ Princess Cruises } \\
\hline Grand Princess & NW Europe/NE Atlantic & Caribbean \\
\hline Golden Princess & Caribbean & Caribbean \\
\hline Star Princess & Mediterranean & Caribbean \\
\hline Caribbean Princess & Caribbean & Caribbean \\
\hline Sapphire Princess & Alaska & Mexican Riviera \\
\hline Diamond Princess & Alaska & Asia / Pacific \\
\hline \multicolumn{3}{|c|}{ Royal Caribbean Cruise Line } \\
\hline Voyager of the Seas & Caribbean & Caribbean \\
\hline Explorer of the Seas & Caribbean & Caribbean \\
\hline Adventure of the Seas & Caribbean & Caribbean \\
\hline Navigator of the Seas & Caribbean & Caribbean \\
\hline Mariner of the Seas & Caribbean & Caribbean \\
\hline
\end{tabular}

SOURCES: SHIPPAX'S GUIDE 2004 AND CRUISE LINES' WEB SITES

This situation will last for at least ten years, before a new set of larger locks are eventually built to improve dramatically the accessibility of the Panama Canal, as planned currently by the Panama Canal Authority. These new locks will be conceived to accommodate very large bulkers or container ships, and there should be no problem for cruise ships up to 200,000 gt to be able to transit this artificial waterway. At least as far as their length, their beam and their water draft are concerned, but the limiting factor will be their air draft, because of the two bridges built across the canal. Therefore, the future generation of panamax cruise ships will be longer and wider than the current overpanamaxes, but these vessels will not be higher on water. And in order to minimize the number of less popular inside cabins, they will feature internal atria (like already for Royal Caribbean Cruise Line's giants) or even open pool or garden areas between two blocks of balcony cabins on each side.

In the meantime, new operational patterns will be explored by current overpanamax owners, the first of which being year-round cruising in the Mediterranean by keeping there their mega ships in winter (Ridolfi, 2000). At least two of the three overpanamaxes of Costa Crociere are due to stay year-round in the Mediterranean. And if it keeps growing at the same pace as in the last five years, it is likely that Mediterranean Shipping Cruises will be the first independant line to enter into the overpanamax era and that they will keep such ships year-round in the Mediterranean, as their non European base is too narrow. The Asia Pacific area, especially South East Asia, whose forthcoming rise makes little doubt (Douglas \& Douglas, 2004), is another likely operational theatre for overpamanaxes, and this has already been explored seasonally by Princess Cruises, in tandem with Alaska or Europe. However, cruising there year-round is a more logical 
option for a regionally based line like Star Cruises, with new Asian-tailored tonnage if, as the regional economic climate is now better, they consider again an earlier project of overpanamaxes.

\section{Conclusion}

51 The cruise shipping industry has experienced the same type of evolution as the container shipping industry, but at a much faster rate and, on the whole, to a higher degree. Both industries, whose sizes are very different, are the product of a revolution, either technical or commercial. A few major features are summarized in tabular form at Table 14 to highlight the main similarities and differences identified in the paper in respect with the topics that have been explored into greater details.

Table 14. The container and cruise shipping industries compared.

\begin{tabular}{|c|c|c|}
\hline & Container shipping & Cruise shipping \\
\hline Iwo shioping rovolutions & $\begin{array}{l}\text { From general cargo to con- } \\
\text { tainers } \\
\text { (tochnical revolution) }\end{array}$ & $\begin{array}{l}\text { From passenger liners to } \\
\text { cruise ships } \\
\text { (commercial revolution) }\end{array}$ \\
\hline Size of the industry & $\begin{array}{l}\text { Very large and global } \\
\text { (Asia/Pacific is the largest } \\
\text { market) }\end{array}$ & $\begin{array}{l}\text { Quite small and Americary } \\
\text { European-based } \\
\text { (Asia/Pacific is a secondary } \\
\text { markot) }\end{array}$ \\
\hline$\frac{\text { Recent dvnamics (1994-2003) }}{\text { (as measured by two proxies) }}$ & $\begin{array}{l}\text { Very dramatic growth (+ } 477.5 \\
\% \text { for TEUs at world's top } \\
50 \text { container ports) }\end{array}$ & $\begin{array}{l}\text { Slightly less dramatic, yet } \\
\text { impressive growth ( }+342 \% \\
\text { for CLIA passengers) }\end{array}$ \\
\hline $\begin{array}{l}\text { Ownershie eoncentration at } \\
\text { corporate level } \\
\text { (as at the end of } 2002 \text {, before } \\
\text { the merger between Carnival } \\
\text { and P\&O Princess) }\end{array}$ & $\begin{array}{l}\text { Leader accounts for only } 129 \% \\
\text { Top four account for just } 26.7 \% \\
\text { (TEUs for collular fleet in ser- } \\
\text { vice) }\end{array}$ & $\begin{array}{l}\text { Leader accounts for as much } \\
\text { as } 33.2 \% \\
\text { Top four acoount for not less } \\
\text { than } 73.1 \% \\
\text { (lower berths for vessels in } \\
\text { service) }\end{array}$ \\
\hline $\begin{array}{l}\text { Imbortance of brands within a } \\
\text { group }\end{array}$ & $\begin{array}{l}\text { Limited (in most cases, only } \\
\text { one brand) }\end{array}$ & Major factor of differentiation \\
\hline$\frac{\text { Saries of (quasi) identical ves:- }}{\text { sels. }}$ & $\begin{array}{l}\text { Rather short, given the size of } \\
\text { the industry }\end{array}$ & $\begin{array}{l}\text { Rather long, given the size of } \\
\text { the industry }\end{array}$ \\
\hline $\begin{array}{l}\text { Role of panarnax-sized ves- } \\
\text { Sels }\end{array}$ & $\begin{array}{l}\text { Workhorses of the world fleot, } \\
\text { at least on the East-West } \\
\text { trades }\end{array}$ & $\begin{array}{l}\text { Owned only by the major } \\
\text { lines, and used mainly in } \\
\text { North America and Europe }\end{array}$ \\
\hline $\begin{array}{l}\text { Entry into the overpanamax } \\
\text { era }\end{array}$ & 1987 (transpacific) & 1996 (Caribbean) \\
\hline $\begin{array}{l}\text { Use of overpanamax-sized } \\
\text { vessels }\end{array}$ & $\begin{array}{l}\text { Widespread among all major } \\
\text { lines } \\
\text { All major trades, except NE } \\
\text { Asia/ECNA }\end{array}$ & $\begin{array}{l}\text { Only for the three largest } \\
\text { groups (five lines) } \\
\text { Mainly in the Caribbean, but } \\
\text { diversification }\end{array}$ \\
\hline $\begin{array}{l}\text { Main shipbuilders of over- } \\
\text { ganamaxes }\end{array}$ & $\begin{array}{l}\text { Mainly Asian yards (but one } \\
\text { Danish) }\end{array}$ & $\begin{array}{l}\text { Mainly European yards (but } \\
\text { one Japanese) }\end{array}$ \\
\hline
\end{tabular}

52 On the one hand, on the corporate front, a concentration process took place, leading to four, then now just three dominant groups of cruise lines wherein several brands are covering different qualitative or geographic segments of the market. The concentration degree is much higher than for the container industry and one may even ask if the recent merger between Carnival Corporation and P\&O Princess Cruises to form the dual-listed Carnival Corporation/plc is not one step too far in this process. It will be difficult to reach again a balanced competitive situation, unless the Royal Caribbean and Star groups merge also. Anyhow, the gap between the majors and the medium-sized players will remain much larger than in the container industry.

53 On the other hand, on the technical front, the cruise shipping industry has entered massively in the panamax and overpanamax eras in a search for economies of scale, with rather long series of more or less similar ships (including for different brands in the same 
group) in a search for economies of scope. These recent series of standardized vessels form a much higher share of the world cruise fleet than what can be seen in the container industry. This reinforces the competitive position of the large cruise groups versus their smaller independent competitors. At the same time, the relationships of these groups with the shipyards have evolved, and a concentration process could also happen in the shipbuilding industry. Finally, the Panama Canal is still a limiting factor, both technically and geographically, but less than previously as cruise lines have found or will implement new operational patterns for their very large tonnage, in the same way as container lines did previously.

\section{BIBLIOGRAPHY}

ALIX Y., SLACK B., COMTOIS C. (1999), «Alliances or acquisitions? Strategies for growth in the container shipping industry. The case of CP Ships», Journal of Transport Geography, 7, pp. 203-208.

ARNOLD P., CHARLIER J. (1999), «Panorama contemporain de l'offre mondiale de croisière», Acta Geographica, 120, pp. 3-16.

CARIOU P. (2000), «Les économies d'échelle dans le transport maritime de lignes régulières», Cahiers Scientifiques du Transport, 37, pp. 75-96.

CASTELJON R., CHARLIER J. (eds.) (2000), El renacer de los cruceros: la mundializacion de los negocios turisticos y maritimos, Fundacion Portuaria, Madrid.

CHARLIER J. (1996), «Les nouvelles frontières du secteur des croisières», Transports, 380, pp. 462-474.

CHARLIER J. (2000a), «An introduction to the geography of cruise shipping», in CASTELJON R., CHARLIER J. (eds.), El renacer de los cruceros: la mundializacion de los negocios turisticos y maritimos, Fundacion Portuaria, Madrid, pp. 17-24.

CHARLIER J. (2000b), «De la norme panamax à l'essor des overpanamax», Acta Geographica, 121, pp. 102-111.

CHARLIER J., ARNOLD P. (1997), «Les complémentarités saisonnières du marché mondial des croisières», Bulletin de la Société Belge d'Études Géographiques, 66, pp. 181-198.

CLIA (2004), The Cruise Industry: an Overview, Cruise Lines International Association, New York.

CONTAINERISATION INTERNATIONAL (2003), Yearbook 2003, Informa, London.

CULLINANE K., KHANNA M. (2000), «Economies of scale in large containerships: optimal size and geographical implications», Journal of Transport Geography, 8, pp. 181-195.

DICKINSON B., VLADIMIR A. (1997), Selling the Sea. An Inside Look at the Cruise Industry, Wiley, Chichester.

DOUGLAS N., DOUGLAS N. (2004), «Pacific cruise tourism», in DOWLING R. (ed.), Cruise Tourism: Issues, Impacts, Cases, CABI Publishing, Wallingford (forthcoming). 
DOWLING R. (ed.) (2004), Cruise Tourism: Issues, Impacts, Cases, CABI Publishing, Wallingford (forthcoming).

DURAND J.-F. (2004), Paquebots autour du monde. Cruise ships around the world, Marines Éditions, Nantes.

FRÉMONT A., SOPPÉ M. (2004), «Les stratégies des armateurs de lignes régulières en matière de dessertes mari times», Belgeo, 4, pp. 391-406.

HALL D. (2004), «Ocean cruising: market dynamics, product responses and onshore impacts», in PINDER D. \& SLACK B. (eds.), Shipping and Ports in the 21st Century. Globalisation, Techno logical Change and the Environment, Routledge, London, pp. 99-130.

ISRAEL G., MILLER L. (1999), Dictionary of the Cruise Industry, Seatrade Cruise Academy, Colchester. HILLING D, BROWNE M. (1998), «Ships, ports and bulk freight industry», in HOYLE B. \& KNOWLES R. (eds.), Modern Transport Geography, Wiley, Chichester, pp. 241-261.

KLEIN R. (2003), Cruising - Out of Control: the Cruise Industry, the Environment, Workers and the Maritimes, Canadian Centre for Policy Alternatives, Halifax.

LIM S.-M. (1998), «Economies of scale in container shipping», Maritime Policy and Management, 25, pp. 361-373.

MCCALLA R., CHARLIER J (2004), «Round the world cruising: a geography created by geography», in DOWLING R. (ed.), Cruise Tourism: Issues, Impacts, Cases, CABI Publishing, Wallingford (forthcoming).

MARCADON J. (2004), «Quelques conséquences de l'arrivée prochaine des mega porteconteneurs», Belgeo, 5, 4, pp. 419-432.

MIDDLEMISS N. (1997), World Cruise Ships. The History and Development of Cruising, Shield Publications, Newcastle-upon-Tyne.

MILLER A., GRAZIER W. (2004), «The North American cruise market», in DOWLING R. (ed.), Cruise Tourism: Issues, Impacts, Cases, CABI Publishing, Wallingford (forthcoming).

MILLER W. (2003), Picture History of SS United States, Dover Publications, Mineola, NY.

PEISLEY T. (1997), The World Cruise Ship Industry to 2000, Travel and Tourism Intelligence, London. PEISLEY T. (2004), Global Changes in the Cruise Industry 2003-2010, Seatrade, Colchester.

RIDOLFI G. (2000), «The new myth of Ulysses. Cruising in the Mediterranean», in CASTELJON R., CHARLIER J. (eds.), El renacer de los cruceros: la mundializacion de los negocios turisticos y maritimos, Fundacion Portuaria, Madrid, pp. 136-154.

SHIPPAX (2004), Guide 2004. Ferry, Cruise and Ro-Ro Register Yearbook, ShipPax Information, Halmstad.

SLACK B. (1998), «Intermodal transportation», in HOYLE B. \& KNOWLES R., Modern Transport Geography, Wiley, Chichester, PP. 263-289.

SLACK B. (ed.) (1999), «Containerisation: the Atlantic and beyond», GeoJournal, 48 (special issue), pp. $1-80$.

SLACK B., COMTOIS C., MCCALLA R. (2001), «Strategic alliances in the container shipping industry: a global perspective», Maritime Policy and Management, 28, pp. 65-76.

WARD D. (2004), Ocean Cruising and Cruise Ships 2004, Berlitz Publishing, London. 
WILD P., DEARING J. (1999), Maritime Tourism to the Year 2004, G.P. Wild International, Haywards Heath

WILD P., DEARING J. (2004a), Outlook and new opportunities for the cruise industry to 2014, G.P. Wild International, Haywards Heath.

WILD P., DEARING J. (2004b), Prospects for the global container trades to 2014, G.P. Wild International, Haywards Heath.

WILKINSON P. (2004), «The changing geography of Caribbean cruise geography», in DOWLING R. (ed.), Cruise Tourism: Issues, Impacts, Cases, CABI Publishing, Wallingford (forthcoming).

\section{ABSTRACTS}

After container shipping, the cruise shipping industry has entered recently into the overpanamax era, in a typical quest for economies of scale, at the same time as it was searching for economies of scope, including through corporate mergers. To some extent, the evolution has been indeed similar, but there are also some major differences.

On the one hand, it is obvious that building always larger ships, from infrapanamax to panamax and finally to overpanamax standards, has brought significant savings in building and operational cost per lower berth for the cruise industry as per TEU in container shipping. And it is also obvious that, besides these economies of scale, building quite long series of ships for the same line or for sister lines has also been an attractive option for the cruise lines. Moreover, in an another search for economies of scope, some cruise lines did not only expand organically, but also externally, again as for container shipping, buying some of their competitors and integrating their ships into their fleet after harmonizing the products. Or alternatively, they may have kept the existing brands, because they had either a well-established global reputation or a strong regional basis. This has led to the formation of a few major groups whose spatial reach is now global, the largest of which is by far Carnival Corporation/plc, born in 2003 from the merger of Carnival Corporation and Princess Cruises.

But on the other hand, there are significant differences between the two industries, one of which being that the dominance of Carnival Corporation/plc is much more overwhelming in the cruise industry than that, in container shipping, of the AP Moller group (itself incorporating two of the previous industry leaders). Moreover, cruise ships are not standardized products as containerships are. The most important difference is that same hull can be used to build similar ships for brands of the same qualitative level, or even quite different ships of different qualitative levels within the same cruise lines' group. Another major difference is that the cruise industry is still dominated, by far, by American or European-based groups or lines, and that most cruise ships have been and are being built at European yards.

Après le secteur des conteneurs, celui des croisières maritimes est récemment entré dans l'ère overpanamax, dans une quête typique d'économies d'échelle au moment même où il était à la recherche d'économies d'envergure au travers d'une série de fusions armatoriales. Jusqu'à un certain point, ces évolutions ont été semblables, mais certaines importantes différences s'observent également.

D'une part, il est évident que la mise en service d'unités toujours plus grandes, aux gabarits infra panamax, puis panamax et enfin overpanamax, a permis, dans le domaine des croisières, des économies significatives aux niveaux constructif et opérationnel en termes de coût par lit bas comme par EVP dans le domaine des conteneurs. Et il apparaît aussi que, outre ces économies d'échelle, la construction de séries relativement longues d'unités pour la même compagnie ou pour des sociétés soeurs a également été une option attractive pour les armements de croisière. 
De plus, dans une autre quête d'économies d'envergure, certains d'entre eux se sont développés de manière organique mais aussi externe, à nouveau comme pour les conteneurs, acquérant certains de leurs concurrents et intégrant leurs navires dans leurs flottes après une harmonisation des produits. Alternativement, les marques existantes ont été conservées, parce qu'elles avaient une réputation bien établie, globalement ou régionalement. Cela a conduit à la constitution de quelques groupes majeurs d'envergure spatiale globale, le plus important étant de loin la Carnival Corporation/plc résultant de la fusion, en 2003, de la Carnival Corporation et de P\&O Princess Cruises.

Mais d'un autre côté, il y a des différences significatives entre les deux secteurs, dont l'une est que la domination de Carnival Corporation/plc est beaucoup plus écrasante que celle, dans le domaine des conteneurs, du groupe AP Muller qui inclut pourtant lui-même un armement né de la fusion de deux anciens leaders mondiaux. De plus, les navires de croisière ne sont pas des produits standardisés comme des porte-conteneurs. La différence la plus importante est que la même coque peut être utilisée pour construire des navires similaires pour des marques de niveau qualitatif identique au sein du même groupe, voire des unités assez différentes de niveaux qualitatifs différents. Une autre différence est que le secteur des croisières est toujours dominé, de loin, par des groupes ou des compagnies basés aux USA ou en Europe, et que la plupart des unités ont été et continuent à être construites dans des chantiers européens.

\section{INDEX}

Mots-clés: croisières maritimes, transport maritime conteneurisé, économies d'échelle, économies d'envergure, fusions armatoriales, navires panamax, navires overpanamax

Keywords: cruise shipping, container shipping, economies of scale, economies of scope, corporate mergers, panamax ships, overpanamax ships

\section{AUTHOR}

\section{JACQUES CHARLIER}

Department of Geography, Catholic University of Louvain, Louvain-la-Neuve, Belgium, charlier@geog.ucl.ac.be 